\title{
Is Use of Micro-RNA-Containing Food Feasible?
}

\author{
Jin-Wook Kang ${ }^{1,2}$, Hyun-Ah Baek ${ }^{3}$, Sung-Dae Cho ${ }^{4^{*}}$ and Jeong-Sang Lee ${ }^{1,2,3^{*}}$ \\ ${ }^{1}$ Department of Functional Food and Biotechnology, College of Medical Science, Jeonju University, Republic of Korea \\ ${ }^{2}$ Department of Integrated Bio-Resource Science, General Graduate School of Jeonju University, Republic of Korea \\ ${ }^{3}$ Food Industry Research Institute, Jeonju University, Republic of Korea \\ ${ }^{4}$ Department of Oral Pathology and Cancer Biology, School of Dentistry, Chonbuk National University, Jeonju, 561-756, Republic of Korea
}

Correspondence to:

Sung-Dae Cho, DVM, PhD

Departments of Oral Pathology and Cancer Biology, School of Dentistry and Institute of Oral

Bioscience, Chonbuk National University

Jeonju 54896, Republic of Korea

Tel: 82-63-270-4027

Fax: 82-63-270-4025

E-mail: efiwdsc@chonbuk.ac.kr

Jeong-Sang Lee, $\mathrm{PhD}$

Food Industry Research Institute

Department of Functional Food and Biotechnology

College of Medical Science, Jeonju University

Jeonju, 55069, Republic of Korea

Tel: 82-63-220-4660

Fax: 82-63-220-2054

E-mail: jslee11@jj.ac.kr

Received: November 15, 2015

Accepted: February 16, 2016

Published: February 19, 2016

Citation: Kang JW, Baek HA, Cho SD, Lee JS 2016. Is Use of Micro-RNA-Containing Food Feasible? J Food Chem Nanotechnol 2(1): 42-49.

Copyright: (C) 2016 Kang et al. This is an Open Access article distributed under the terms of the Creative Commons Attribution 4.0 International License (CC-BY) (http://creativecommons. org/licenses/by/4.0/) which permits commercial use, including reproduction, adaptation, and distribution of the article provided the original author and source are credited.

Published by United Scientific Group

\section{Abstract}

Micro-RNAs (miRNAs) are a class of small non-coding single-strand RNA molecules ( $22 \mathrm{nt}$ in length) that play an important role in inhibition of translation or degradation of targeted messenger RNAs (mRNAs) by binding 3'-untranslated region (UTR) of target mRNAs. MiRNAs are involved in diverse physiological and pathological processes, including apoptosis, cell proliferation, the cell cycle, carcinogenesis and skeletal muscle function. On this basis, miRNAs can be used to combat disease and maintain health. MiRNAs may also facilitate development of enhanced food or feed. We assessed three factors required for use of miRNAs in food: stability, safety, and efficacy. This review highlights emerging evidence in the use of miRNAs as ingredients in food or animal feed. We also discuss the challenges to, and perspectives for, the application of miRNAs.

\section{Keywords}

Micro-RNAs, Anti-sense oligonucleotide (ASO), Mimic nucleotide (mimic), Functional foods

\section{Introduction}

Micro-RNAs (miRNAs) are a class of small endogenous non-coding RNAs that bind their target gene through perfect or imperfect base-pair complementarity. The first miRNAs discovered in Caenorbabditis elegans by Victor Ambros and Gary Ruvkun [1] were Lin-4 and let-7. Lin-4 negatively regulates the level of LIN-14 protein by imperfect complementary base pairing with the 3'UTR of the Lin-14 mRNA. Also, Lin-4 controls the timing of the development of the first larval stage [2], and post-translational inhibition by miRNA was considered to be specific for nematodes. Surprisingly, let-7 is not limited to C. elegans, rather has been highly conserved through evolution in a range of animal species, including vertebrates, invertebrates and humans [3-6]. These findings suggest that miRNAs are present and functional in a variety of organisms.

Recently, miRNA biosynthesis and processing steps have been revisited. Usually, miRNAs are located in the intron of protein-coding genes and transcribed by RNA polymerase II into pri-RNAs with a 5' cap and poly-A tail. Then, the pri-miRNAs are cleaved to pro-miRNAs by the nuclear microprocessor complex, consisting of RNaseIII (Drosha) and the co-factor DGCR8 (DiGerge critical region 8). Pre-miRNAs are then exported to the cytoplasm by Exportin- 5 and further processed. The next processing enzyme, Dicer, an RNase III-type endonuclease, cleaves the hairpins of pre-miRNAs, resulting in double-strand RNA duplexes. They are dissociated by Ago2, which unwinds the double- 
stranded RNA duplexes. The mature miRNAs are retained in the RNA-induced silencing complex (RISC) and bind to the 3'-untranslated region (UTR) of target $\mathrm{mRNAs}$ to regulate expression. Subsequently, miRNAs regulate mRNA expression by inducing degradation or translational repression [1-8].

Interestingly, the involvement of miRNAs in diverse physiological and pathological aspects has been revealed. For instance, miR-21 functions as an oncogene by regulating many tumor suppressor genes and is upregulated in many human malignancies $[9,10]$, including breast cancer $[11$, 12], glioblastoma [13], hepatocellular carcinoma [14], cholangiocarcinoma [15], lung cancer [16], tongue squamous cell carcinoma [17], gastric cancer $[18,19]$, colorectal cancer [20, 21], and prostate cancer [22]. Moreover, evidence is accumulating that many age-related diseases are also associated with impaired cell signaling cascades. The miRNA control systems linked with the cell cycle, DNA repair, oxidative stress responses and apoptosis are abnormally expressed in midlife $[23,24]$. Two heart-specific miRNAs were deleted in a large proportion of offspring mouse models, which resulted in abnormal heart development [25]. While these lethal effects were expected, another study suggested a subtler role for miRNA in the heart. When miR-208 was eliminated, the mice appeared normal; however, defects were revealed when their hearts were stressed $[25,26]$. These results suggest that miRNA studies should be extended to the diagnosis of heart disease. Numerous reports have demonstrated the role of miRNAs in neural development. Evidence for the role of miRNA in Parkinson's disease comes from animal models indicated that loss of miRNAs may be involved in disease development and progression $[27,28]$. In cell culture, transfer of small RNA fragments preserved the loss of function in certain miRNA-deficient nerve cells [29, 30]. While these and other results supported an important role for miRNA in neurodegenerative disorders, further work is needed to delineate the exact role of miRNAs in this important area. Recent miRNA deletion studies have revealed a central role in the regulation of the immune response. The deletion of miRNA-155 impaired $\mathrm{T}$ and $\mathrm{B}$ cell differentiation in germinal centers, and greatly decreased antibody and cytokine production. miRNA-181 and -223 were found to control the T-cell response and granulocyte production, respectively. As more roles for miRNAs in the immune response are found, the list of immune function disorders with a miRNA component will also increase [31-33].

The miRNAs can be transmitted from one species to another, which can result in cross-species regulation of gene expression. Many evidences suggest that food-derived exogenous miRNAs exist in blood and organs of mammals, where they serve functions similar to endogenous miRNAs and simultaneously regulate either multiple target genes or biological processes [34-45]. Thus endogenous miRNAs of one species may influence the biologic functions of another, distantly related species (Figure 1).

Epigenetics can be defined as heritable changes in gene expression that do not involve changes to the underlying DNA sequence, a change in phenotype without a change in genotype [46]. They consist of DNA methylation, histone modifications, RNA interference and chromatin remodeling without alteration of DNA sequence. Epigenetic modifications can be altered by external or internal environmental factors and have the ability to change gene expression. In this context, nutritional epigenetics is important, because food can modify physiologic processes through epigenetic regulation of gene expression [46-48].

However, whether miRNA itself or miRNA-containing food can be included in the human diet or animal feed remains open to speculation.

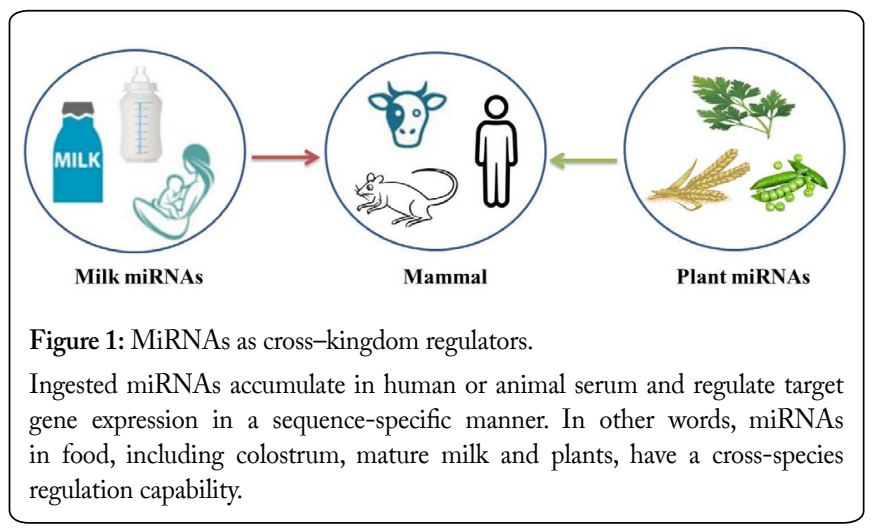

\section{Milk and Plant miRNAs}

\section{Milk containing miRNAs}

Milk contains abundant miRNAs in period of breastfeeding. Hundreds of miRNAs have been discovered by sequencing and microarray analysis in multiplex milks such as bovine [49-55], human [34, 35, 56, 57], rat [60], goat [61], and porcine $[62,63]$. Immune-related miRNAs in milk have been speculated to play a crucial role in the development of the immune system in newborn infants $[50,54,56]$. Especially, the MiRNA concentration in colostrum is higher than that in mature milk $[49,50,64]$. $\mathrm{Li}$ et al. reported the miRNA expression profiles of lactating and non-lactating bovine mammary glands [55]. Milk miRNAs are stable in harsh environments, such as the digestive tract. In contrast, synthetic miRNAs were degraded at $37^{\circ} \mathrm{C}$, at a low $\mathrm{pH}$ (up to $\mathrm{pH} 1$ ) and by RNase $[50,51]$. MiRNAs are packaged in a variety of vesicles, including microvesicles (MVs) and exosomes [51, 53, 54, 57, 65-67]. Such vesicles may allow miRNAs to tolerate degradation in the gastrointestinal tract and be absorbed in the intestine. These coated and/or protected miRNAs could resist the food manufacturing process and be absorbed into the intestine.

\section{Plant miRNAs}

MiRNA-containing foods are found in animals and plant resources $[68,69]$ and dietary miRNA can affect the circulating miRNA profile to regulate the expression of human genes [34, 35, 70-72]. Zhang et al. and Vaucheret reported three important findings $[34,72]$. First, some of the plant miRNAs in human serum are genuine plant miRNAs. Also, they were detected in MVs. Second, plant miRNAs were stable in cooked food and could pass through the mouse GI tract. Third, an exogenous plant miRNA, miR-168a, binds to mammalian 
low-density lipoprotein receptor adapter 1 (LDLRAP1) and decreases the LDLRAP1 protein level. Indeed, the addition of mammalian miR-150 to mice feed downregulated hepatic c-Myb expression of the fed mice. Plant-derived miRNAs (e.g., rice and bean) are stable during food processing, cooking and early digestion (up to $75 \mathrm{~min}$ ). In contrast, synthetic miRNAs were unstable under identical condition [70]. These findings suggested that vesicles, such as exosome and MVs, can also play a key role in protecting exogenous miRNAs against cooking, food processing and digestion and facilitating their delivery to their target gene.

\section{Cross-Kingdom Activity of miRNAs}

Milk-derived miRNAs regulate gene expression in mammals

Colostrum is a complex liquid that provides immunity to the infant and affects maturation of the infant's immune system, particularly the miRNAs in the colostrum [56, 66]. Baier et al. reported that humans absorb biologically meaningful amounts of miRNAs from nutritionally relevant doses of cow's milk [35]. They concluded that miRNAs in milk are bioactive food compounds that regulate the expression of human genes [35]. Melnik et al. suggested a new option for prevention of atopic diseases-addition of physiological amounts of miR-155-enriched exosomes in raw cow's milk to infant formula for mothers incapable of breastfeeding [36]. In contrast, Melnik provided evidence of the pathogenic role of persistent milk signaling in mTORC1- and milk-miRNAdriven type 2 diabetes mellitus [37]. These findings suggest that milk-containing miRNAs regulate mammalian gene expression either beneficially or harmfully.

\section{Plant miRNAs regulate gene expression in mammals}

Exogenous plant miRNAs in food regulate the expression of target genes in mammals [34, 38-41]. Zhou et al. and Yang et al. detected plant miRNAs in the sera and tissue of honeysuckle-fed mice [39,40]. Yang et al.suggested that dietary uptake of MIR-2911 was common in healthy consumers, and reproducible detection of plant-based miRNAs in healthy consumers depended on their dietary abundance (food intake), RNA stability, and digestion [41]. Liang et al. performed a kinetic study of plant miRNAs in human plasma after drinking watermelon juice [42]. Watermelon-derived miRNAs are selectively taken up and some plant miRNAs have a similar concentration as compared with endogenous miRNAs in the plasma. Mlotshwa et al. engineered plant-derived artificial miRNAs that could silence essential human oncogenes and thereby had potential as a cancer therapeutic [43]. Yang et al. and Wagner et al. reported on diverse aspects-including the uptake, delivery, and function-of dietary miRNAs and plantbased miRNAs in mammals [44, 45].

\section{Miravirsen, the First miRNA-targeted Antiviral Drug in Phase 3 Trials}

miR-122, known as a hepatitis $\mathrm{C}$ virus (HCV)-specific miRNA, is highly expressed in the liver and plays an important role in $\mathrm{HCV}$ infection [73-77]. Especially, miR-122 binds to the $5^{\prime}$ untranslated region (5'UTR) of the HCV genome, unlike other miRNA which usually binds to 3 ' untranslated region of target mRNAs. Then, miR-122 forms an oligomeric miR-122-HCV complex, which not only protects the $\mathrm{HCV}$ genome from nucleotide degradation and/or host innate immune responses, but also leads to upregulation of $\mathrm{HCV}$ replication in infected liver cells [73-77]. Miravirsen (SPC3649) is a chemically modified anti-miR oligonucleotide and the first anti-miR drug candidate for treatment of $\mathrm{HCV}$ infection, which targets miR-122. Locked nucleic acids (LNAs) is a bicyclic RNAs in which the ribose ring is locked by introduction of a 2'-O, 4'-C methylene bridge, resulting the antisense-oligonucleotides (ASOs) showing a high affinity for the target site $[78,79]$. Clinical safety and efficacy testing of miravirsen in a phase 2a clinical study has been completed [80]. Miravirsen resulted in a dose-dependent reduction in HCV RNA levels in 36 patients receiving 3, 5, and $7 \mathrm{mg}$ per $\mathrm{kg}$ body weight, with the exception of one patient in the $5 \mathrm{mg}$ group and four patients in the $7 \mathrm{mg}$ group. Five patients in the miravirsen groups had side effects of moderate severity, including headache, otitis externa, pelvic bone injury after a fall, syncope and flulike symptoms. Studied of miravirsen have not indicated side effect in animals [80, 81]. However, the only serious side effect was loss of consciousness in one patient [82]. Exogenous and even chemically modified miRNAs can exert a prolonged anti-viral effect. Dangerous side effects that can occur due to the multi-targeting ability of miRNA did not occur except for one patient in the clinical trial. Miravirsen is now preparing a phase 3 clinical trial. Therefore, based on the targeting of miR-122 with miravirsen, design of functional foods containing miRNA antisense or mimic oligonucleotide seems feasible.

\section{Micro-RNAs in Nutrition Act as Epigenetic Regulators}

Nutritional epigenetics can modify physiologic processes through epigenetic regulation of gene expression [46-48]. Various nutrients-such as vitamins, methionine, choline, folate, and betaine-can affect DNA modification, and bioactive compounds-including vitamins, fatty acids, curcumin and resveratrol-can regulate the expression of miRNAs $[8,48$, $83,84]$. These recent findings suggested that nutrients and bio-compounds in food either directly participate in gene regulation or indirectly affect post-transcriptional regulation by regulating miRNA expression. The nutrients and/or biochemicals that regulate miRNA expression are summarized in Table 1. Although research on the relationship between food and miRNA gene expression or regulation is limited, it will be worthy to check the possibility of synergic effect through the combination of meaningful miRNAs as an ingredient of food for human health.

\section{Conclusion and Perspectives}

MiRNAs influence cellular processes by regulating their target gene though suppression or degradation. Several 


\begin{tabular}{|c|c|c|c|}
\hline & Upregulated miRNAs & Downregulated miRNAs & References \\
\hline Vitamin A & $\begin{array}{c}\text { let-7a-3, let-7c, let-7d, miR-15a, miR-15b, miR- } \\
\text { 16-1, miR-107, miR-186, miR-215, miR-223, } \\
\text { miR-223, miR-342, }\end{array}$ & $\begin{array}{l}\text { let-7a, miR-17-5p, miR-181b, miR-25, miR-193, } \\
\text { miR-195 }\end{array}$ & [91-93] \\
\hline Vitamin B (folate) & $\operatorname{miR}-222$ & & [94] \\
\hline Vitamin D & miR-22, miR-32, miR-98, miR-182 & $\operatorname{miR}-181$ & [95-99] \\
\hline Curcumin & miR-22 & miR-21, miR-186, miR-199a & [100-102] \\
\hline Resveratrol & miR-150, miR-663, miR-296-5p & $\begin{array}{l}\operatorname{miR}-7, \operatorname{miR}-17, \operatorname{miR}-18 b, \mathrm{miR}-20 \mathrm{a}, \mathrm{miR}-106 \mathrm{a} \\
\mathrm{miR}-106 \mathrm{~b}\end{array}$ & [103-105] \\
\hline Ellagitannins & $\begin{array}{c}\text { let-7e, } \operatorname{miR}-370, \text { miR-373, miR-526b, let-7a, } \\
\text { miR-29a }\end{array}$ & let-7a, let-7c, and let-7d, miR-197, miR-373 & {$[106,107]$} \\
\hline Genistein & & miR-27a, miR-221, miR-222 & {$[108,109]$} \\
\hline Catechins & $\begin{array}{l}\text { let-7a, miR-7-1, miR-16, miR-34a, miR-99a, } \\
\text { miR-210, miR-221, miR-330 }\end{array}$ & $\begin{array}{l}\text { miR-18a, miR-21, miR-34b, miR-92, miR-93, } \\
\text { miR-106b, miR-193b, miR-222, miR-342 }\end{array}$ & [110-113] \\
\hline Isoflavones & let-7b, let-7e, miR-146a, miR-200b, miR-200c, & & {$[114,115]$} \\
\hline Indol (DIM) & $\begin{array}{l}\text { let-7b, let-7e, miR-21, miR-146a, miR-200b, } \\
\text { miR-200c }\end{array}$ & & {$[114,115]$} \\
\hline SCFA butyrate & & $\begin{array}{l}\text { miR-17, miR-20a, miR-20b, miR-93, miR-106a, } \\
\text { miR-106b }\end{array}$ & [116] \\
\hline Oleic acid & $\mathrm{miR}-21$ & & [117] \\
\hline
\end{tabular}

DIM, 3',3'-diindolylmethane; SCFA butyrate, short chain fatty acid butyrate

miRNAs are specifically up- and/or down expressed in various disease states, research into use of miRNAs as biomarkers or therapeutics is underway. However, there is little interest in use of miRNA in food or animal feed, due to issues such as absorption, degradation during food processing or digestion, and side effects (Figure 2). In this review of dietary miRNA, such as plant miRNAs and milk miRNAs, we confirmed the possibility of their application in food or animal feed. miRNAs stable under harsh conditions ( $\mathrm{pH} \mathrm{1,} \mathrm{RNase,} 37^{\circ} \mathrm{C}$ ) which is associated with their packaging into vesicles, including exosomes and MVs. Conde et al. reported that self-assembled RNA-triple-helix conjugates remain functional in vitro and in vivo, and that they induce $90 \%$ tumor shrinkage in a triplenegative breast cancer mouse model [85]. An RNA-triplehelix structure is created by two miRNAs, an miRNA mimic (tumor suppressor miRNA) and an antagomiR (oncomiR inhibitor). This is a new means of improving the stability of exogenous miRNAs in mammalian systems. In addition, ingested miRNAs can regulate human gene expression. The greatest obstacles in clinical miRNA research are unexpected side effects due to the multi-targeting ability of miRNAs. The phase 2 clinical study of miravirsen, the first miRNA inhibitor drug candidate, reported no serious side effects except for one case and there was no adverse effect in animal testing. A negative or positive relationship between miRNA and nutrients would be an important factor for their use in food or animal feed. As found additional role of nutrients on the indirectly inhibition of the gene via the miRNA, synergic effect between nutrients and dietary miRNA would be also possible. The relationship between foods and miRNAs is highly associated at the epigenetics mechanistic support. Therefore, miRNAs or

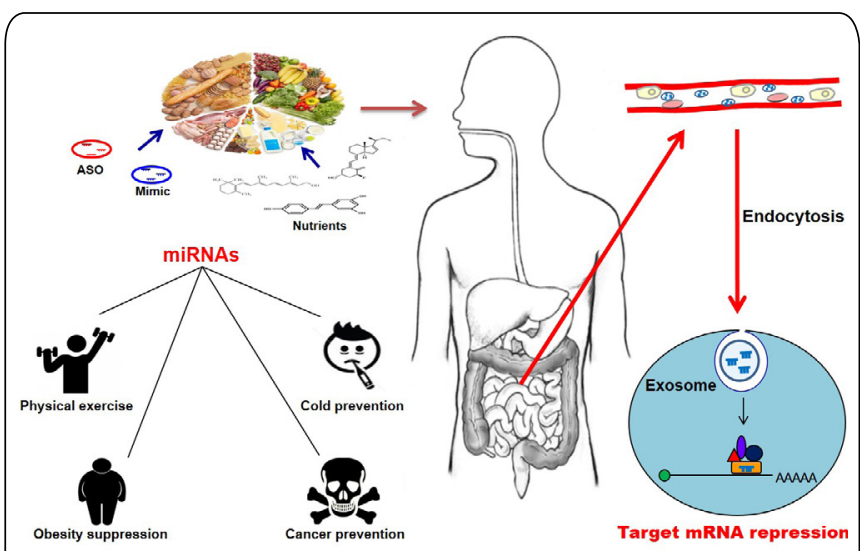

Figure 2: MiRNA-containing food can be designed to regulate specific target genes.

ASO and/or mimic of miRNAs associated with specific disease enable exogenous control in the body. The high-tech level functional food can be achieved by combining several core mi-RNAs mimics or antisense oligonucleotides that can selectively suppress target gene expression under physiologic conditions. Core miRNAs involved in various processes such as physical exercise [86, 87], cough prevention or release [88], obesity [89, 90], and cancer prevention [8] would be effective resource for food or animal feed. We can apply not only mimics of the core miRNAs as tumor suppress gene but also ASO of core miRNAs as oncogene with combination strategy. Packaging of artificial ASO and/or miRNA mimics within exosomes maintains their stability during digestion. MiRNA-containing foods are absorbed in the intestine and the miRNAs delivered to the bloodstream. Endocytosis of the exosome results in delivery of miRNAs and regulation of the expression of their target genes. Use of miRNAs in food may be an effective method of disease prevention by synergic combination of miRNA modulation and phytochemicals. For example, miRNA mimics that suppress expression of cancer-causing genes are packaged in vesicles, and biologically meaningful amounts of packaged miRNAs can be added to food. Use of such combinations of common miRNAs will facilitate development. 
miRNA-containing biomaterials (ASO or mimics) may be useful function food ingredients to prevent and treat various diseases.

\section{Conflict of Interest}

The authors do not have any conflict of interest regarding this mini-review.

\section{Acknowledgements}

This study was supported by the National Research Foundation of Korea (KRF) grant funded by the Korea government (Ministry of Science, ICT and future planning) (No. 2015R1C1A1A01053520).

\section{Authors Contributions}

Jin-Wook Kang and Hyun-Ah Baek are contributed equally to this work.

\section{References}

1. Stenvang J, Petri A, Lindow M, Obad S, Kauppinen S. 2012. Inhibition of microRNA function by antimiR oligonucleotides. Silence 3(1): 1. doi: 10.1186/1758-907X-3-1

2. Lee RC, Feinbaum RL, Ambros V. 1993. The C. elegans heterochronic gene lin-4 encodes small RNAs with antisense complementarity to lin14. Cell 75(5): 843-854. doi:10.1016/0092-8674(93)90529-Y

3. Roush S, Slack FJ. 2008. The let-7 family of microRNAs. Trends Cell Biol 18(10): 505-516. doi: 10.1016/j.tcb.2008.07.007

4. Pasquinelli AE, Reinhart BJ, Slack F, Martindale MQ, Kuroda MI, et al. 2000. Conservation of the sequence and temporal expression of let-7 heterochronic regulatory RNA. Nature 408(6808): 86-89. doi: $10.1038 / 35040556$

5. Lagos-Quintana M, Rauhut R, Meyer J, Borkhardt A, Tuschl T. 2003. New microRNAs from mouse and human. RNA 9(2): 175-179. doi: 10.1261/rna.2146903

6. Bashirullah A, Pasquinelli AE, Kiger AA, Perrimon N, Ruvkun G, et al. 2003. Coordinate regulation of small temporal RNAs at the onset of Drosophila metamorphosis. Dev Biol 259(1): 1-8. doi: 10.1016/S00121606(03)00063-0

7. He L, Hannon GJ. 2004. MicroRNAs: small RNAs with a big role in gene regulation. Nat Rev Genet 5(7): 522-531. doi: 10.1038/nrg1379

8. Yi B, Piazza GA, Su X, Xi Y. 2013. MicroRNA and cancer chemoprevention. Cancer Prev Res (Phila) 6(5): 401-409. doi: 10.1158/1940-6207.CAPR-13-0032

9. Pan X, Wang ZX, Wang R. 2010. MicroRNA-21: a novel therapeutic target in human cancer. Cancer Biol Ther 10(12): 1224-1232. doi: $10.4161 / \mathrm{cbt} .10 .12 .14252$

10. Volinia S, Calin GA, Liu CG, Ambs S, Cimmino A, et al. 2006. A microRNA expression signature of human solid tumors defines cancer gene targets. Proc Natl Acad Sci USA 103(7): 2257-2261. doi: 10.1073/ pnas. 0510565103

11. Yan LX, Huang XF, Shao Q, Huang MY, Deng L, et al. 2008. MicroRNA miR-21 overexpression in human breast cancer is associated with advanced clinical stage, lymph node metastasis and patient poor prognosis. $R N A$ 14(11): 2348-2360. doi: 10.1261/rna.1034808

12. Iorio MV, Ferracin M, Liu CG, Veronese A, Spizzo R, et al. 2005. MicroRNA gene expression deregulation in human breast cancer. Cancer Res 65(16): 7065-7070. doi: 10.1158/0008-5472.CAN-05-1783
13. Gabriely G, Wurdinger T, Kesari S, Esau CC, Burchard J, et al. 2008. MicroRNA 21 promotes glioma invasion by targeting matrix metalloproteinase regulators. Mol Cell Biol 28(17): 5369-5380. doi: 10.1128/MCB.00479-08

14. Meng F, Henson R, Wehbe-Janek H, Ghoshal K, Jacob ST, et al. 2007. MicroRNA-21 regulates expression of the PTEN tumor suppressor gene in human hepatocellular cancer. Gastroenterology 133(2): 647-658. doi: 10.1053/j.gastro.2007.05.022

15. Selaru FM, Olaru AV, Kan T, David S, Cheng Y, et al. 2009. MicroRNA-21 is overexpressed in human cholangiocarcinoma and regulates programmed cell death 4 and tissue inhibitor of metalloproteinase 3. Hepatology 49(5): 1595-1601. doi: 10.1002/ hep.22838

16. Seike M, Goto A, Okano T, Bowman ED, Schetter AJ, et al. 2009. MiR-21 is an EGFR-regulated anti-apoptotic factor in lung cancer in never-smokers. Proc Natl Acad Sci USA 106(29): 12085-12090. doi: 10.1073/pnas.0905234106

17. Li J, Huang H, Sun L, Yang M, Pan C, et al. 2009. MiR-21 indicates poor prognosis in tongue squamous cell carcinomas as an apoptosis inhibitor. Clin Cancer Res 15(12): 3998-4008. doi: 10.1158/1078-0432. CCR-08-3053

18. Zhang Z, Li Z, Gao C, Chen P, Chen J, et al. 2008. miR-21 plays a pivotal role in gastric cancer pathogenesis and progression. Lab Invest 88(12): 1358-1366. doi: 10.1038/labinvest.2008.94

19. Chan SH,Wu CW,Li AF, Chi CW,Lin WC. 2008. miR-21 microRNA expression in human gastric carcinomas and its clinical association. Anticancer Res 28(2A): 907-911.

20. Asangani IA, Rasheed SA, Nikolova DA, Leupold JH, Colburn NH, et al. 2008. MicroRNA-21 (miR-21) post-transcriptionally downregulates tumor suppressor Pdcd4 and stimulates invasion, intravasation and metastasis in colorectal cancer. Oncogene 27(15): 2128-2136. doi: 10.1038/sj.onc. 1210856

21. Yu Y, Sarkar FH, Majumdar AP. 2013. Down-regulation of miR21 induces differentiation of chemoresistant colon cancer cells and enhances susceptibility to therapeutic regimens. Transl Oncol 6(2): 180186

22. Folini M, Gandellini P, Longoni N, Profumo V, Callari M, et al. 2010. miR-21: an oncomir on strike in prostate cancer. Mol Cancer 9: 12. doi: 10.1186/1476-4598-9-12

23. Noren Hooten N, Fitzpatrick M, Wood WH 3rd, De S, Ejiogu N, et al. 2013. Age-related changes in microRNA levels in serum. Aging (Albany NY) 5(10): 725-740.

24. Noren Hooten N, Abdelmohsen K, Gorospe M, Ejiogu N, Zonderman $\mathrm{AB}$, et al. 2010. microRNA expression patterns reveal differential expression of target genes with age. PLoS One 5(5): e10724. doi: 10.1371/journal.pone.0010724

25. Ono K, Kuwabara Y, Han J. 2011. MicroRNAs and cardiovascular diseases. FEBS J 278(10): 1619-1633. doi: 10.1111/j.17424658.2011.08090.x

26. Dong DL, Yang BF. 2011. Role of microRNAs in cardiac hypertrophy, myocardial fibrosis and heart failure. Acta Pharmaceutica Sinica B 1(1): 1-7. doi: 10.1007/s10557-011-6289-5

27. Miñones-Moyano E, Porta S, Escaramís G, Rabionet R, Iraola S, et al. 2011. MicroRNA profiling of Parkinson's disease brains identifies early downregulation of $\mathrm{miR}-34 \mathrm{~b} / \mathrm{c}$ which modulate mitochondrial function. Hum Mol Genet 20(15): 3067-3078. doi: 10.1093/hmg/ddr210

28. Heman-Ackah SM, Hallegger M, Rao MS, Wood MJ. 2013. RISC in PD: the impact of microRNAs in Parkinson's disease cellular and molecular pathogenesis. Front Mol Neurosci 6: 40. doi: 10.3389/ fnmol.2013.00040

29. Gokey NG, Srinivasan R, Lopez-Anido C, Krueger C, Svaren J. 2012. Developmental regulation of microRNA expression in Schwann cells. Mol Cell Biol 32(2): 558-568. doi: 10.1128/MCB.06270-11 
30. Kye MJ, Gonçalves Ido C. 2014. The role of miRNA in motor neuron disease. Front Cell Neurosci 8: 15. doi: 10.3389/fncel.2014.00015

31. Lu LF, Liston A. 2009. MicroRNA in the immune system, microRNA as an immune system. Immunology 127(3): 291-298. doi: 10.1111/j.13652567.2009.03092.x

32. Lindsay MA. 2008. microRNAs and the immune response. Trends Immunol 29(7): 343-351. doi: 10.1016/j.it.2008.04.004

33. Davidson-Moncada J, Papavasiliou FN, Tam W. 2010. MicroRNAs of the immune system: roles in inflammation and cancer. Ann NY Acad Sci 1183: 183-194. doi: 10.3748/wjg.v19.i20.2985

34. Zhang L, Hou DX, Chen X, Li DH, Zhu LY, et al. 2012. Exogenous plant MIR168a specifically targets mammalian LDLRAP1: evidence of cross-kingdom regulation by microRNA. Cell Res 22(1): 107-126. doi: 10.1038/cr.2011.158

35. Baier SR, Nguyen C, Xie F, Wood JR, Zempleni J. 2014. MicroRNAs are absorbed in biologically meaningful amounts from nutritionally relevant doses of cow milk and affect gene expression in peripheral blood mononuclear cells, HEK-293 kidney cell cultures, and mouse livers. J Nutr 144(10): 1495-1500. doi: 10.3945/jn.114.196436

36. Melnik BC, John SM, Schmitz G. 2014. Milk: an exosomal microRNA transmitter promoting thymic regulatory $\mathrm{T}$ cell maturation preventing the development of atopy? J Transl Med 12: 43. doi: 10.1186/14795876-12-43

37. Melnik BC. 2015. The pathogenic role of persistent milk signaling in mTORC1- and milk-microRNA-driven type 2 diabetes mellitus. Curr Diabetes Rev 11(1): 46-62.

38. Liang HW, Zen K, Zhang JF, Zhang CY, Chen X. 2013. New roles for microRNAs in cross-species communication. RNA Biol 10(3): 367-370. doi: 10.4161/rna.23663

39. Zhou Z, Li X, Liu J, Dong L, Chen Q, et al. 2015. Honeysuckleencoded atypical microRNA2911 directly targets influenza A viruses. Cell Res 25: 39-49. doi: 10.1038/cr.2014.130

40. Yang J, Farmer LM, Agyekum AA, Hirschi KD. 2015. Detection of dietary plant-based small RNAs in animals. Cell Res 25(4): 517-520. doi: $10.1038 /$ cr.2015.26

41. Yang J, Farmer LM, Agyekum AA, Elbaz-Younes I, Hirschi KD. 2015. Detection of an abundant plant-based small RNA in healthy consumers. PLoS ONE 10(9): 1-14. doi: 10.1371/journal.pone.0137516

42. Liang H, Zhang S, Fu Z, Wang Y, Wang N, et al. 2015. Effective detection and quantification of dietetically absorbed plant microRNAs in human plasma. J Nutr Biochem 26(5): 505-512. doi: 10.1016/j. jnutbio.2014.12.002

43. Mlotshwa S, Pruss GJ, MacArthur JL, Endres MW, Davis C, et al. 2015. A novel chemopreventive strategy based on therapeutic microRNAs produced in plants. Cell Res 25(4): 521-524. doi:10.1038/cr.2015.25

44. Yang J, Hirschi KD, Farmer LM. 2015. Dietary RNAs: New stories regarding oral delivery. Nutrients 7(5): 3184-3199. doi:10.3390/ nu7053184

45. Wagner AE, Piegholdt S, Ferraro M, Pallauf K, Rimbach G. 2015. Food derived microRNAs. Food Funct 6(3): 714-718. doi: 10.1039/ C4FO01119H

46. Choi SW, Friso S. 2010. Epigenetics: A new bridge between nutrition and health. Adv Nutr 1(1): 8-16. doi: 10.3945/an.110.1004

47. Landecker H. 2011. Food as exposure: Nutritional epigenetics and the new metabolism. Biosocieties 6(2):167-194. doi:10.1057/biosoc.2011.1

48. Paul B, Barnes S, Demark-Wahnefried W, Morrow C, Salvador C, et al. 2015. Influences of diet and the gut microbiome on epigenetic modulation in cancer and other diseases. Clin Epigenetics 7: 112.

49. Hata T, Murakami K, Nakatani H, Yamamoto Y, Matsuda T, et al. 2010. Isolation of bovine milk-derived microvesicles carrying mRNAs and microRNAs. Biochem Biophys Res Commun 396(2): 528-533. doi: 10.1016/j.bbrc.2010.04.135

50. Izumi H, Kosaka N, Shimizu T, Sekine K, Ochiya T, et al. 2012. Bovine milk contains microRNA and messenger RNA that are stable under degradative conditions. J Dairy Sci 95(9): 4831-4841. doi: 10.3168/ jds.2012-5489

51. Kosaka N, Izumi H, Sekine K, Ochiya T. 2010. microRNA as a new immune-regulatory agent in breast milk. Silence 1(1): 7. doi: 10.1186/1758-907X-1-7

52. Lawless N, Vegh P, O'Farrelly C, Lynn DJ. 2014. The role of microRNAs in bovine infection and immunity. Front Immunol 5: 611. doi: 10.3389/ fimmu.2014.00611

53. Reinhardt TA, Lippolis JD, Nonnecke BJ, Sacco RE. 2012. Bovine milk exosome proteome. J Proteomics 75(5): 1486-1492. doi: 10.1016/j. jprot.2011.11.017

54. Sun J, Aswath K, Schroeder SG, Lippolis JD, Reinhardt TA, et al. 2015. MicroRNA expression profiles of bovine milk exosomes in response to Staphylococcus aureus infection. BMC Genomics 16(1): 806. doi: 10.1186/ s12864-015-2044-9

55. Li Z, Liu H, Jin X, Lo L, Liu J. 2012. Expression profiles of microRNAs from lactating and non-lactating bovine mammary glands and identification of miRNA related to lactation. BMC Genomics 13: 731. doi: 10.1186/1471-2164-13-731

56. Zhou Q, Li M, Wang X, Li Q, Wang T, et al. 2012. Immune-related microRNAs are abundant in breast milk exosomes. Int J Biol Sci 8(1):118-123

57. Munch EM, Harris RA, Mohammad M, Benham AL, Pejerrey SM, et al. 2013. Transcriptome profiling of microRNA by Next-Gen deep sequencing reveals known and novel miRNA species in the lipid fraction of human breast milk. PLoS One 8(2): e50564. doi: 10.1371/ journal.pone.0050564

58. Weber JA, Baxter DH, Zhang S, Huang DY, Huang KH, et al. 2010. The microRNA spectrum in 12 body fluids. Clin Chem 56(11): 17331741. doi: $10.1373 /$ clinchem. 2010.147405

59. Alsaweed M, Hartmann PE, Geddes DT, Kakulas F. 2015. Micrornas in breast milk and the lactating breast: potential immunoprotectors and developmental regulators for the infant and the mother. Int J Environ Res Public Health 12(11): 13981-14020. doi:10.3390/ijerph121113981

60. Izumi H, Kosaka N, Shimizu T, Sekine K, Ochiya T, et al. 2014. Timedependent expression profiles of microRNAs and mRNAs in rat milk whey. PLoS One 9(2): e88843. doi: 10.1371/journal.pone.0088843

61. Mobuchon L, Marthey S, Le Guillou S, Laloë D, Le Provost F, et al. 2015. Food deprivation affects the mirnome in the lactating goat mammary gland. PLoS One 10(10): e0140111. doi: 10.1371/journal. pone. 0140111

62. Gu Y, Li M, Wang T, Liang Y, Zhong Z, et al. 2012. Lactation related microRNA expression profiles of porcine breast milk exosomes. PLoS One 7(8): e43691. doi: 10.1371/journal.pone.0043691

63. Chen T, Xi QY, Ye RS, Cheng X, Qi QE, et al. 2014. Exploration of microRNAs in porcine milk exosomes. BMC Genomics 15: 100. doi: 10.1186/1471-2164-15-100

64. Chen X, Gao C, Li H, Huang L, Sun Q, et al. 2010. Identification and characterization of microRNAs in raw milk during different periods of lactation, commercial fluid, and powdered milk products. Cell Res 2010(10): 1128-1137. doi: 10.1038/cr.2010.80

65. Zhang J, Sha L, Lu L, Meng L, Chongye G, et al. 2015. Exosome and exosomal microRNA: trafficking, sorting, and function. Genomics Proteomics Bioinformatics 13(1): 17-24. doi: 10.1016/j.gpb.2015.02.001

66. Kosaka N, Iguchi H, Ochiya T. 2010. Circulating microRNA in body fluid: a new potential biomarker for cancer diagnosis and prognosis. Cancer Sci 101(10):2087-2092. doi: 10.1111/j.1349-7006.2010.01650.x

67. Montecalvo A, Larregina AT, Shufesky WJ, Stolz DB, Sullivan ML, et al. 2012. Mechanism of transfer of functional microRNAs between mouse dendritic cells via exosomes. Blood 119(3): 756-766. doi: 10.1182/blood-2011-02-338004

68. Chiang K, Shu J, Zempleni J, Cui J. 2015. Dietary MicroRNA Database (DMD): an archive database and analytic tool for food- 
borne microRNAs. PLoS One 10(6): e0128089. doi: 10.1371/journal. pone. 0128089

69. Liang GF, Zhu YL, Sun B, Shao YH, Jing AH, et al. 2014. Assessing the survival of exogenous plant microRNA in mice. Food Sci Nutr 2(4): 380-388. doi: 10.1002/fsn3.113

70. Philip A, Ferro VA, Tate RJ. 2015. Determination of the potential bioavailability of plant microRNAs using a simulated human digestion process. Mol Nutr Food Res 59(10): 1962-1972. doi: 10.1002/ mnfr.201500137

71. Witwer KW. 2012. XenomiRs and miRNA homeostasis in health and disease: Evidence that diet and dietary miRNAs directly and indirectly influence circulating miRNA profiles. RNA Biol 9(9): 1147-1154. doi: 10.4161/rna.21619

72. Vaucheret H, Chupeau Y. 2012. Ingested plant miRNAs regulate gene expression in animals. Cell Res 22(1): 3-5. doi: 10.1038/cr.2011.164

73. Gupta P, Cairns MJ, Saksena NK. 2014. Regulation of gene expression by microRNA in HCV infection and HCV-mediated hepatocellular carcinoma. Virol J 11: 64. doi:10.1186/1743-422X-11-64

74. Shimakami T, Yamane D, Jangra RK, Kempf BJ, Spaniel C, et al. 2012. Stabilization of hepatitis $\mathrm{C}$ virus RNA by an Ago2-miR-122 complex. Proc Natl Acad Sci USA 109(3): 941-946.

75. Jopling CL, Schütz S, Sarnow P. 2008. Position-dependent function for a tandem microRNA miR-122-binding site located in the hepatitis C virus RNA genome. Cell Host Microbe 4(1): 77-85. doi:10.1016/j. chom.2008.05.013

76. Machlin ES, Sarnow P, Sagan SM. 2011. Masking the 5' terminal nucleotides of the hepatitis $\mathrm{C}$ virus genome by an unconventional microRNA-target RNA complex. Proc Natl Acad Sci USA 108(8): 31933198. doi: $10.1073 /$ pnas. 1012464108

77. Gebert LF, Rebhan MA, Crivelli SE, Denzler R, Stoffel M, et al. 2014. Miravirsen (SPC3649) can inhibit the biogenesis of miR-122. Nucleic Acids Res 42(1): 609-621. doi: 10.1093/nar/gkt852

78. Petersen M, Wengel J. 2003. LNA: a versatile tool for therapeutics and genomics. Trends Biotechnol 21(2): 74-81. doi:10.1016/S01677799(02)00038-0

79. Lindow M, Kauppinen S. 2012. Discovering the first microRNAtargeted drug. J Cell Biol 199(3): 407-412. doi: 10.1083/jcb.201208082

80. Elmén J, Lindow M, Silahtaroglu A, Bak M, Christensen M, et al. 2008. Antagonism of microRNA-122 in mice by systemically administered LNA-antimiR leads to up-regulation of a large set of predicted target mRNAs in the liver. Nucleic Acids Res 36(4): 1153-1562. doi: 10.1093/ nar/gkm1113

81. Janssen HL, Reesink HW, Lawitz EJ, Zeuzem S, Rodriguez-Torres M, et al. 2013. Treatment of HCV infection by targeting microRNA. $N$ Engl J Med 368(18): 1685-1694. doi: 10.1056/NEJMoa1209026

82. Lanford RE, Hildebrandt-Eriksen ES, Petri A, Persson R, Lindow M, et al. 2010. Therapeutic silencing of microRNA-122 in primates with chronic hepatitis C virus infection. Science 327(5962): 198-201. doi: 10.1126/science. 1178178

83. Parasramka MA, Ho E, Williams DE, Dashwood RH. 2012. MicroRNAs, diet, and cancer: new mechanistic insights on the epigenetic actions of phytochemicals. Mol Carcinog 51(3): 213-230. doi: $10.1002 / \mathrm{mc} .20822$

84. Phuah NH, Nagoor NH. 2014. Regulation of microRNAs by natural agents: new strategies in cancer therapies. Biomed Res Int 2014: 804510

85. Conde J, Oliva N, Atilano M, Song HS, Artzi N. 2015. Self-assembled RNA-triple-helix hydrogel scaffold for microRNA modulation in the tumour microenvironment. Nat Mater. doi: 10.1038/nmat4497

86. Huang ZP, Espinoza-Lewis R, Wang DZ. 2012. Determination of miRNA targets in skeletal muscle cells. Methods Mol Biol 798: 475-490. doi: 10.1007/978-1-61779-343-1_28

87. Güller I, Russell AP. 2010. MicroRNAs in skeletal muscle: their role and regulation in development, disease and function. J Physiol 588(Pt
21): 4075-4087. doi: 10.1113/jphysiol.2010.194175

88. Mesel-Lemoine M, Millet J, Vidalain PO, Law H, Vabret A, et al. 2012. A human coronavirus responsible for the common cold massively kills dendritic cells but not monocytes. J Virol 86(14): 7577-7587. doi: 10.1128/JVI.00269-12

89. Sun L,Xie H, Mori MA, Alexander R, Yuan B, et al. 2011. Mir193b-365 is essential for brown fat differentiation. Nat Cell Biol 13(8): 958-965. doi: $10.1038 /$ ncb2286

90. McGregor RA, Choi MS. 2011. microRNAs in the regulation of adipogenesis and obesity. Curr Mol Med 11(4): 304-316. doi: 10.2174/156652411795677990

91. Garzon R, Pichiorri F, Palumbo T, Visentini M, Aqeilan R, et al. 2007. MicroRNA gene expression during retinoic acid-induced differentiation of human acute promyelocytic leukemia. Oncogene 26(28): 4148-4157. doi:10.1038/sj.onc.1210186

92. Careccia S, Mainardi S, Pelosi A, Gurtner A, Diverio D, et al. 2009. A restricted signature of miRNAs distinguishes APL blasts from normal promyelocytes. Oncogene 28(45): 4034-4040. doi:10.1038/onc.2009.255

93. Rossi A, D’Urso OF, Gatto G, Poltronieri P, Ferracin M, et al. 2010. Non-coding RNAs change their expression profile after Retinoid induced differentiation of the promyelocytic cell line NB4. BMC Res Notes 3: 24. doi: 10.1186/1756-0500-3-24

94. Marsit CJ, Eddy K, Kelsey KT. 2006. MicroRNA responses to cellular stress. Cancer Res 66(22): 10843-10848. doi: 10.1158/0008-5472. CAN-06-1894

95. Gocek E, Wang X, Liu X, Liu CG, Studzinski GP.2011.MicroRNA-32 upregulation by 1,25-dihydroxyvitamin D3 in human myeloid leukemia cells leads to Bim targeting and inhibition of AraC-induced apoptosis. Cancer Res 71(19): 6230-6239. doi: 10.1158/0008-5472.CAN-11-1717

96. Ting HJ, Messing J, Yasmin-Karim S, Lee YF. 2013. Identification of microRNA-98 as a therapeutic target inhibiting prostate cancer growth and a biomarker induced by vitamin D. J Biol Chem 288(1): 1-9. doi: 10.1074/jbc.M112.395947

97. Alvarez-Díaz S, Valle N, Ferrer-Mayorga G, Lombardía L, Herrera M, et al. 2012. MicroRNA-22 is induced by vitamin D and contributes to its antiproliferative, antimigratory and gene regulatory effects in colon cancer cells. Hum Mol Genet 21(10): 2157-2165. doi: 10.1093/hmg/ dds031

98. Wang X, Gocek E, Liu CG, Studzinski GP. 2009. MicroRNAs181 regulate the expression of $\mathrm{p} 27 \mathrm{Kip} 1$ in human myeloid leukemia cells induced to differentiate by 1,25-dihydroxyvitamin D3. Cell Cycle 8(5): 736-741. doi: $10.4161 / \mathrm{cc} .8 .5 .7870$

99. Peng X, Vaishnav A, Murillo G, Alimirah F, Torres KE, et al. 2010. Protection against cellular stress by 25-hydroxyvitamin D3 in breast epithelial cells. J Cell Biochem 110(6): 1324-1333. doi: 10.1002/ jcb. 22646

100.Mudduluru G, George-William JN, Muppala S, Asangani IA, Kumarswamy R, et al. 2011. Curcumin regulates miR-21 expression and inhibits invasion and metastasis in colorectal cancer. Biosci Rep 31(3): 185-197. doi: 10.1042/BSR20100065

101.Sun M, Estrov Z, Ji Y, Coombes KR, Harris D, et al. 2008. Curcumin (diferuloylmethane) alters the expression profiles of microRNAs in human pancreatic cancer cells. Mol Cancer Ther 7(3): 464-673. doi: 10.1158/1535-7163.MCT-07-2272

102.Zhang J, Du Y, Wu C, Ren X, Ti X, et al. 2010. Curcumin promotes apoptosis in human lung adenocarcinoma cells through miR186* signaling pathway. Oncol Rep 24(5): 1217-1223. doi: 10.3892/ or_00000975

103.Tili E, Michaille JJ, Adair B, Alder H, Limagne E, et al. 2010. Resveratrol decreases the levels of miR- 155 by upregulating miR-663, a microRNA targeting JunB and JunD. Carcinogenesis 31(9): 1561-1566. doi: $10.1093 /$ carcin/bgq143

104.Tili E, Michaille JJ,Alder H, Volinia S, Delmas D, et al.2010. Resveratrol modulates the levels of microRNAs targeting genes encoding tumor- 
suppressors and effectors of TGF $\beta$ signaling pathway in SW480 cells. Biochem Pharmacol 80(12): 2057-2065. doi:10.1016/j.bcp.2010.07.003

105.Dhar S, Hicks C, Levenson AS. 2011. Resveratrol and prostate cancer: promising role for microRNAs. Mol Nutr Food Res 55(8): 1219-1229. doi: 10.1002/mnfr.201100141

106.Ai RT, Wu SY, Wen XY, Xu W, Lv L, et al. 2011. 1,3,4-tri-O-galloyl6-O-caffeoyl- $\beta$-D-glucopyranose, a new anti-proliferative ellagitannin, regulates the expression of microRNAs in HepG(2) cancer cells. Nan Fang Yi Ke Da Xue Xue Bao 31(10): 1641-1648.

107.Wen XY, Wu SY, Li ZQ, Liu ZQ, Zhang JJ, et al. 2009. Ellagitannin (BJA3121), an anti-proliferative natural polyphenol compound, can regulate the expression of MiRNAs in HepG2 cancer cells. Phytother Res 23(6): 778-784. doi: 10.1002/ptr.2616

108.Sun Q, Cong R, Yan H, Gu H, Zeng Y, et al. 2009. Genistein inhibits growth of human uveal melanoma cells and affects microRNA-27a and target gene expression. Oncol Rep 22(3): 563-567. doi: 10.3892/ or_00000472

109. Chen Y, Zaman MS, Deng G, Majid S, Saini S, et al. 2011. MicroRNAs 221/222 and genistein-mediated regulation of ARHI tumor suppressor gene in prostate cancer. Cancer Prev Res (Phila) 4(1): 76-86. doi: $10.1158 / 1940-6207$

110.Chakrabarti M, Khandkar M, Banik NL, Ray SK. 2012. Alterations in expression of specific microRNAs by combination of 4-HPR and EGCG inhibited growth of human malignant neuroblastoma cells. Brain Res 1454: 1-13. doi: 10.1016/j.brainres.2012.03.017

111.Wang H, Bian S, Yang CS. 2011. Green tea polyphenol EGCG suppresses lung cancer cell growth through upregulating miR-210 expression caused by stabilizing HIF-1 $\alpha$. Carcinogenesis 32(12): 18811889. doi: $10.1093 /$ carcin/bgr218

112.Siddiqui IA, Asim M, Hafeez BB, Adhami VM, Tarapore RS, et al. 2011. Green tea polyphenol EGCG blunts androgen receptor function in prostate cancer. FASEB J 25(4): 1198-1207. doi: 10.1096/fj.10167924

113.Tsang WP, Kwok TT. 2010. Epigallocatechin gallate up-regulation of miR-16 and induction of apoptosis in human cancer cells. J Nutr Biochem 21(2): 140-146. doi: 10.1016/j.jnutbio.2008.12.003

114.Li Y, Vandenboom TG $2^{\text {nd }}$, Wang Z, Kong D, Ali S, et al. 2010. miR146a suppresses invasion of pancreatic cancer cells. Cancer Res 70(4): 1486-1495. doi: 10.1158/0008-5472.CAN-09-2792

115.Li Y, VandenBoom TG 2 $2^{\text {nd }}$, Kong D, Wang Z, Ali S, et al. 2009. Up-regulation of miR-200 and let-7 by natural agents leads to the reversal of epithelial-to-mesenchymal transition in gemcitabineresistant pancreatic cancer cells. Cancer Res 69(16): 6704-6712. doi: 10.1158/0008-5472.CAN-09-1298

116.Hu S, Dong TS, Dalal SR, Wu F, Bissonnette M, et al. 2011. The microbe-derived short chain fatty acid butyrate targets miRNAdependent p21 gene expression in human colon cancer. PLoS One 6(1): e16221. doi: 10.1371/journal.pone.0016221

117.Vinciguerra M, Sgroi A, Veyrat-Durebex C, Rubbia-Brandt L, Buhler LH, et al. 2009. Unsaturated fatty acids inhibit the expression of tumor suppressor phosphatase and tensin homolog (PTEN) via microRNA-21 up-regulation in hepatocytes. Hepatology 49(4): 11761184. doi: $10.1002 /$ hep. 22737 